$\xi=$

\title{
Phytochemical screening, FT-IR analysis and antimicrobial activity of Wattakaka volubilis
}

\author{
S.Venkatesan $^{1 *}$, V. Balamurugan ${ }^{1}$, A. Sundaresan ${ }^{1}$, P. Susindran $^{1}$, K. Vasanthi ${ }^{1}$, \\ E. Subashini ${ }^{1}$, M. Anithakumari ${ }^{2}$ \\ ${ }^{I}$ Assistant professor, PG and Research Department of Biotechnology, Sri Vinayaga College of Arts and Science, \\ Ulundurpet, 606 107, Tamil Nadu, India \\ ${ }^{2}$ P.G. Student, PG and Research Department of Biotechnology, Sri Vinayaga College of Arts and Science, \\ Ulundurpet, 606 107, Tamil Nadu, India \\ *Corresponding author_E-mail:sel_ven@yahoo.com
}

\begin{abstract}
The present study was evaluated the phytochemical analysis and antibacterial activity of Wattakaka volubilis leaf extract. The Wattakaka volubilis is medicinal plant used in the treatment of various diseases (Wound, diabetics, rheumatic and diarrhea). The ethanol, methanol, petroleum ether and DMSO extract from the leaf of Wattakaka volubilis were screened on their phytochemicals analysis. Among thesePhytochemicals were alkaloids, anthroquione, caumarin, flavanoids, phenols, saponins, steroids, tannins and terpenoids for present in the following extracts ethanol, methanol. The petroleum ether and DMSO only present in several phytochemicals like alkaloid, anthroquinone, terpenoids and tannins. Wattakaka volubilis against the antibacterial like E. coli, B. pumilus, Enterobacter aerogens, and Pseudomonas aeruginosa. The zone of inhibition of Wattkaka voulubilis leaf extract against the bacteria was maximum inhibition Pseudomonas aeruginosa, Enterobacter aerogens, Bacillus pumilis. The least zone of inhibition was recorded against E.coli. The characterization of the plant extract and the functional groups was analyzed in Fourier Transform Infrared Spectroscopy (FTIR). The absorbance bands analysis were observed in the region of $4000-400 \mathrm{~cm}-1$ are 23 compounds derived. The compounds represented the ranges from 3905.21 to 436.41 peaks were shown. This study which is the primary report on the phytochemicals analysis and antibacterial properties of Wattakaka volubilis supports its traditional uses in the treatment of infectious and non- infectious diseases.
\end{abstract}

Keywords: Wattakaka volubilis; Phenols; Ethanol; DMSO; Bacillus Pumilus; Bacteria; Tannin Etc.

\section{Introduction}

India has a rich culture of medicinal herbs which includes about more than 2000 species and has a vast geographical area with high potential abilities for Ayurvedic, Unani and Siddha `medicines but only very few have been studied chemically and pharmacologically for their potential medicinal values (Guptha et al., 2005). Substances derived from the plants remain the basis for a large proportion of the commercial medications used today for the treatment of heart disease, high blood pressure, pain, asthma, and other problems. In recent years, there has been renewed interest in the treatment against different diseases using herbal drugs as they are generally non toxic and World Health Organization has also recommended the evaluation of the effectiveness of plants in condition where we lack safe modern drugs. Plant derivatives with hypoglycaemic properties have been used in folk medicine and traditional healing systems around the world (Yeh, et al., 2003) from very ancient time. Despite the introduction of hypoglycaemic agents from natural and synthetic sources, diabetes and its secondary complications continue to be a major medical problem to people (Ravi, et al., 2005).

The root is applied to snake bites and given to women to cure headache after child birth and the leaves are applied to boils and abscesses to promote suppuration. It is emetic diaphoretic and diuretic (Agarwal, 1986). Traditional; healers of Kerala use its leaves to treat inflammatory and painful conditions (Kirtukar and
Basu, 2003). Wattakaka volubilis (Linn.f.) Stap f (Family - Asclepidaceae) is a large climber with green flowers in drooping umbels, with smooth bark and ash colored, leaves rounded at the base. A large twining shrub older branches ash colored. It is found in India and South East Asia. The plant is tonic, aphrodisiac, antipyretic and astringent to the bowels; good for dyspepsia and inflammations; cures piles, tumours, leucoderma, asthma and urinary discharges. It is also used in colds, eye diseases and sneezing. W. volubilis Leaf paste is removed along with pepper to treat dyspepsia (Pandikumar, et al., 2007). Bark paste, mixed with hot milk is utilized internally for treating urinary troubles (Silija et al., 2008), and leaf powder is taken orally along with cow's milk have antidiabetic activity (Ayyanar et al., 2008)

The literature survey revealed that among the various saponins obtained from the stem and flower of W. volubilis, two compounds are active against Ehrlich's as cites carcinoma (Yoshimura, et al., 1983 and Sahu, et al., 2002). Since W. volubilis has been reported to possess medicinal effects, the anti-inflammatory, analgesic and anti-pyretic activities exhibited by the constituents present in the dried root ethanol extract. Pharmacological activity studies reported earlier on these plants are W. volubilis Antifungal, antibacterial (Vijayal, 2008), hypoglycemic (Jasmine and Daisy, 2004), anti-inflammatory, analgesic and anti-lipid peroxidative (Divya, 2009), protection against selenite induced cataract in rat lens (Biju, et al., 2007), in vitro anti-leishmanial and anti-tumour (Molisha, et al., 2009), hepatotoxicity prevention of proteolysis in 
rat lens (Biju, et al., 2007), apoptosis inducing potential (Subbiah, 2005).

The importance of medicinal plants in traditional health care practices, providing clues to new areas of drug research and biodiversity conservation is now well recognized. Inflammation is a complex biological response of vascular tissues to harmful stimuli such as pathogens, damaged cells and irritants. It is the protective attempt by the organism to remove the injurious stumuli as well as initiate healing process for the tissue and considered to be the major cause of rheumatoid arthritis. Drugs currently used for management of pain and inflammatory conditions present toxic side effects in chronic administration. Therefore, attempts are being taken to study promising plants which may lead to develop newer or safer drugs (Fayyaz, et al., 1994).

\section{Materials and methods}

\subsection{Collection of plant material}

Fresh healthy leaves of Wattakaka volubilis (L.fil.)Stapf were collected from Thanjavur District, Tamilnadu, India, during December 2015. The Flora of Tamil Nadu Carnatic (Matthew, 1983) was used for identification and authentication of the plants. Collected leaf of Wattakaka volubilis washed thoroughly in running tap water, rinsed in distilled water, stored in sterile polythene bags and used for further studies.

\subsection{Preparation of plant extracts}

About two grams leaves of Wattakaka volubilis were taken in $10 \mathrm{ml}$ of different organic solvents, (Ethanol, Methanol, Dimethyl Sulphoxide (DMSO) and Petroleum ether) and crushed with a use of sterile mortar and pestle (Essawi and Srour, 2000). Then the solvent extracts were filtered through Whatman No.1 filter paper and series of sterile filter membranes $(2-20 ; 0.45 ; 0.2 \mu \mathrm{m})$. These prepared leaf extracts were stored in sterile glass bottles at $4^{\circ} \mathrm{C}$ for further use.

\subsection{Chemicals}

All the chemicals used for this work, were purchased from HiMedia, Mumbai, India.

\subsection{Qualitative phytochemical analysis}

The phytochemical analysis was carried out from ethanol leaf extract of Wattakaka volubilis (Linn.) with standard methods (Harbone, 1993). It was done to assess the qualitative chemical composition of crude extracts using commonly employed, precipitation and colorations reaction to identify the major natural chemical groups.

Fourier Transform - Infrared Spectroscopy (FT-IR) Analysis

The methanolic extract of Wattakaka volubilis samples were taken in the foam of fine powder (Saifuddin et al., 2009) and were filtered with sieves of 0.071 and $0.500 \mathrm{~mm}$ mesh size. The FT-IR spectra were recorded in mid IR region $4000-400 \mathrm{~cm}^{-1}$ at the resolution of $4 \mathrm{~cm}^{-1}$ using a sophisticated computer controlled FT-IR Perkin Elmer spectrometer with He-Ne laser as reference. Air back ground spectrum was recorded before each sample.

\subsection{Procurement of test organisms}

Three Gram negative bacteria (Enterobacter aerogenes, Pseudomonas aeruginosa and E.coli) and gram positive bacteria (Bacillus pumilus) were procured from Doctors Diagnostic Centre Trichy, Tamilnadu, India. Bacterial cultures were maintained on nutrient agar slants maintenance at $4^{\circ} \mathrm{C}$ for further experiments.

Determination of antimicrobial activity

\subsection{Preparation of culture Inoculums}

The stock cultures of bacteria (Enterobacteraerogenes, Bacillus pumilus, Pseudomonas aerogenosa and E.coli) used in this study was maintained on nutrient agar slants at $4^{\circ} \mathrm{C}$. Inoculums was prepared by suspending a loop full of bacterial cultures into $10 \mathrm{ml}$ of nutrient broth and was incubated at $37^{\circ} \mathrm{C} \pm 2^{\circ} \mathrm{C}$ for 24 to 48 hours.

\subsection{Agar well-diffusion method}

Agar well-diffusion method was followed to determine the antimicrobial activity (Perez et al., 1990). Nutrient agar plates were swabbed (sterile cotton swabs) with 24 hours culture and 48 hours old broth culture of respective bacteria. Agar wells ( $5 \mathrm{~mm}$ diameter) were made in each of these plates using sterile cork borer. About $100 \mu 1$ of different solvent leaf extracts were added using sterilized dropping pipettes into the wells and plates were left for 1 hour to allow a period of pre-incubation diffusion in order to minimize the effects of variation in time between the applications of different solutions The plates were incubated in an upright position at $37^{\circ} \mathrm{C}$ $\pm 2^{\circ} \mathrm{C}$ for $24 \mathrm{~h}$ for bacterial pathogens.

\section{Results}

\subsection{Preliminary phytochemical screening of whole plant of W.volubilis}

The plant parts of Wattakaka volubilis leaf screening of qualitative phytochemical analysis with different solvents were used such as ethanol, methanol, petroleum ether and DMSO. Among the four solvent the ethanol was maximum extraction of phytochemicals such as alkaloids, anthroquionones, coumarin, flavonoids, phenols, saponins, steriods, tannins and terpenoids were recorded. The methanol extracts of the plant which analysed such as alkaloids, anthroquine, coumarin, flavonoids, phenols where as in the solvent of petroleum ether was alkaloid only presented. The DMSO solvents with Wattakaka volubilis plant extract was only three compounds such as alkaloids, anthroquines and tannins were recorded. However, the solvent was one of the major roles for extract were analysed. The results are tabulated in Table 1.

Table: 1Preliminary Phytochemical Screening of Leaves of Wattakaka Volubilis

\begin{tabular}{llllll}
\hline No. & $\begin{array}{l}\text { Bioactive Com- } \\
\text { pounds }\end{array}$ & Ethanol & Methanol & $\begin{array}{l}\text { Petroleum } \\
\text { ether }\end{array}$ & DMSO \\
\hline 1. & Alkaloids & + & + & + & + \\
2. & Anthroquinones & + & + & + & + \\
3. & Coumarin & + & + & - & - \\
4. & Flavonoids & + & + & - & - \\
5. & Phenols & + & + & - & - \\
6. & Saponins & + & + & - & - \\
7. & Steroids & + & - & - & - \\
8. & Tannins & + & + & - & + \\
9. & Terpenoids & + & + & + & - \\
\hline
\end{tabular}

\subsection{FTIR analysis}

The characterization of the plant extract and the functional groups was analyzed in Fourier Transform Infrared Spectroscopy (FT-IR) The absorbance spectra of soluble plant extract was shown in figure 1 . The absorbance bands analysis were observed in the region of $4000-400 \mathrm{~cm}^{-1}$ are 23 compounds derived. The compounds represented the ranges from 3905.21 to 436.41 peaks were shown Table 2 and Fig 1. 
ACIC
St.Joseph's College ( Autonomous)
Trichy-2

Spectrum Name: J--1.sp

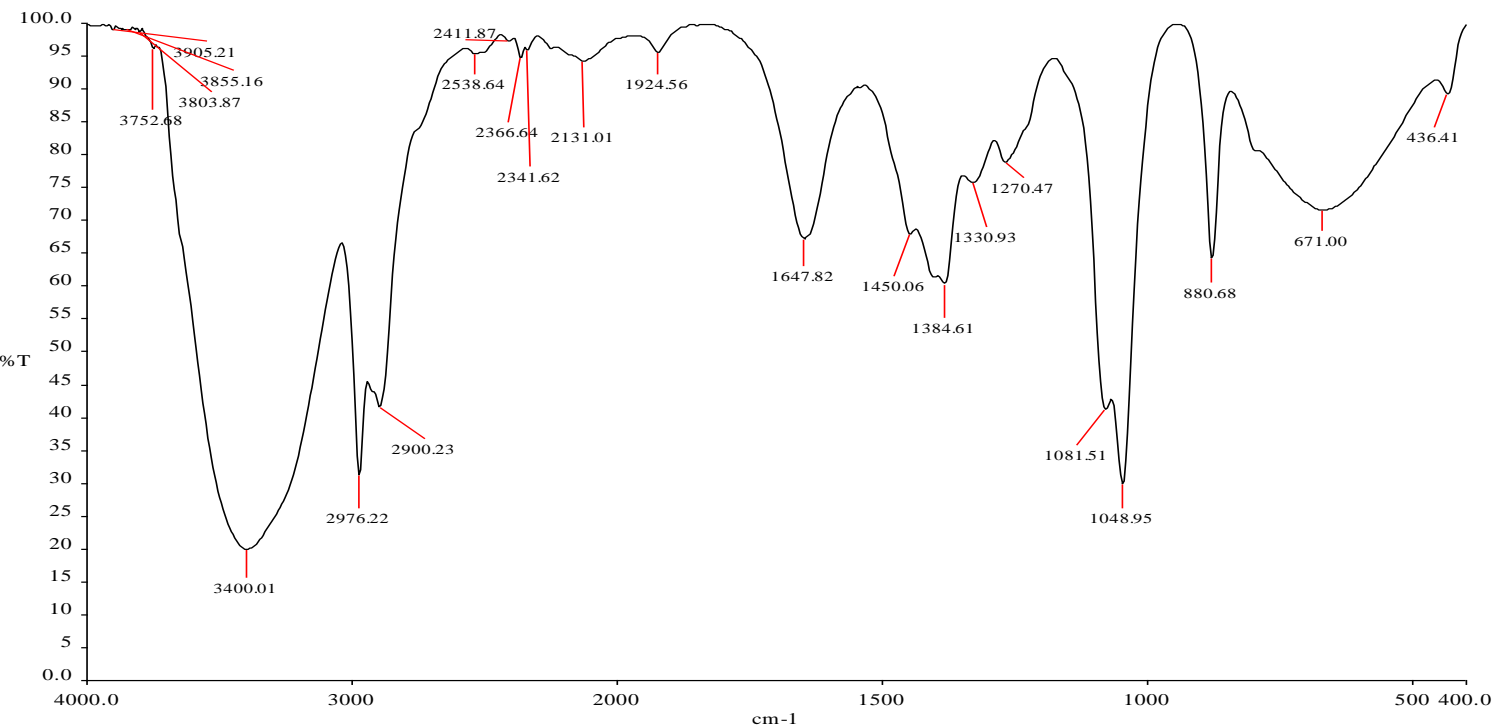

Fig. 1: FT-IR Analysis of Ethanol Extract of Wattakka Volubilis Leaf

Table: 2FTIR Analysis for Ethanol Extracts of Wattakaka Volubilis Leaf

\begin{tabular}{|c|c|c|c|}
\hline $\begin{array}{l}\text { S. } \\
\text { No }\end{array}$ & $\begin{array}{l}\text { Peak } \\
\text { area }\end{array}$ & Bond & Functional group \\
\hline 1 & 3905.21 & O-H stretch & Free hydroxyl alcohols phenols \\
\hline 2 & 3855.16 & C-H stretch & Alkynes \\
\hline 3 & 3803.87 & C H Stretch & Alkynes \\
\hline 4 & 3752.68 & O-H stretch, & free hydroxyl alcohols, phenols \\
\hline 5 & 3400.01 & $\mathrm{~N}-\mathrm{H}$ stretch & $1^{\circ}, 2^{\circ}$ amines, amides \\
\hline 6 & 2976.22 & C-Hstrtch & Alkalans \\
\hline 7 & 2900.23 & C-H bonds & Alkyl C-H Stretch \\
\hline 8 & 2411.87 & $\begin{array}{l}\mathrm{H}-\mathrm{C}=\mathrm{O}: \mathrm{C}-\mathrm{H} \\
\text { stretch }\end{array}$ & Aldehydes \\
\hline 9 & 2538.64 & $\begin{array}{l}\mathrm{H}-\mathrm{C}=\mathrm{O}: \mathrm{C}-\mathrm{H} \\
\text { stretch }\end{array}$ & Aldehydes \\
\hline 10 & 2366.64 & $\begin{array}{l}\mathrm{H}-\mathrm{C}=\mathrm{O}: \mathrm{C}-\mathrm{H} \\
\text { stretch }\end{array}$ & Aldehydes \\
\hline 11 & 2341.62 & C C Stretch & Alkynes: \\
\hline 12 & 2131.01 & $-\mathrm{C} \equiv \mathrm{C}-$ stretch & Alkynes \\
\hline 13 & 1924.56 & $\mathrm{~N}-\mathrm{H}$ Bend & Amines \\
\hline 14 & 1647.82 & $-\mathrm{C}=\mathrm{C}-$ stretch & Alkanes \\
\hline 15 & 1450.06 & $\mathrm{C}-\mathrm{H}$ bend & Alkanes \\
\hline 16 & 1384.61 & $\mathrm{~N}-\mathrm{O}$ stretch & Nitrate \\
\hline 17 & 1330.93 & $\mathrm{C}-\mathrm{N}$ stretch & aromatic amines \\
\hline 18 & 1270.47 & $\begin{array}{l}\mathrm{N}-\mathrm{O} \text { symmetric } \\
\text { stretch }\end{array}$ & nitro compounds \\
\hline 19 & 1081.51 & $\mathrm{C}-\mathrm{O}$ stretch & $\begin{array}{l}\text { alcohols, carboxylic acids, esters, } \\
\text { ethers }\end{array}$ \\
\hline 20 & 1048.95 & $\mathrm{C}-\mathrm{N}$ stretch & aliphatic amines \\
\hline 21 & 880.68 & C-H “oop” & Aromatics \\
\hline 22 & 671.00 & $\mathrm{C}-\mathrm{Br}$ stretch & Alkylhalides \\
\hline 23 & 436.41 & $\mathrm{C}-\mathrm{Br}$ stretch & Alkylhalides \\
\hline
\end{tabular}

\subsection{Antibacterial activity of Wattakaka volubilis}

In the present investigation the effect of antimicrobial activity of Wattakaka volubilis against some clinically important bacterial strains were observed. The ethanolic leaf extract of W. volubilis has showed the highest zone of inhibition against Bacillus pumilus, Enterobacter aerogens, E.coli and Pseudomonas aeruginosa with 13, 15, 2 and $20 \mathrm{~mm}$ in diameter respectively. The zone of inhibition was observed for W.volubilis against Bacillus pumilus and E.coli was 10 and $8 \mathrm{~mm}$ respectively. Whereas, no zone of inhibition in Enterobacter aerogens and Pseudomonas aeruginosa in the methanolic extract. DMSO and Petroleum ether No zone of inhibition was observed from the effect of W.volubilis against the tested bacterial pathogens. The results were recorded in Table 3 .
Table: 3Antibacterial Activities of Wattakaka Volubilis against Some Bacterial Pathogens with Different Solvents

\begin{tabular}{|c|c|c|c|c|}
\hline \multirow{2}{*}{ Bacteria } & \multicolumn{4}{|c|}{ Zone of inhibition (mm) } \\
\hline & Ethanol & Methanol & DMSO & $\begin{array}{l}\text { Petroleum } \\
\text { ether }\end{array}$ \\
\hline Bacillus pumilus & 13 & 10 & - & - \\
\hline Enterobacter aerogens & 15 & - & - & - \\
\hline Escherichia coli & 2 & 8 & - & - \\
\hline $\begin{array}{l}\text { Pseudomonas aeru- } \\
\text { ginosa }\end{array}$ & 20 & - & - & - \\
\hline
\end{tabular}

\section{Discussion}

Antimicrobial activity of Wattakaka volubilis were done against some bacterial pathogens with different solvents. The leaf extract of Wattakaka volubilis showed the maximum zone of inhibition in the ethanol solvent when compared to other solvents such as methanol, DMSO and petroleum ether. No zone formation of DMSO and petroleum ether from the plant extract (Table 1) may be due to the solvent nature and extraction of plant samples. The leaf extracts of Wattakaka volubilis $(20 \mathrm{~mm})$ showed maximum zone of inhibition against Pseudomonas aeruginosa when compared to other bacteria. Methanolic extract of Wattakaka volubilis showed maximum antibacterial activity against Bacillus pumilus $(10 \mathrm{~mm})$ and E.coli $(8 \mathrm{~mm})$. There is no zone of inhibition was observed against Enterobacter aerogens and Pseudomonas aeruginosa. No zone of inhibition was observed in petroleum ether extract against four tested bacteria. The ethanobotanical approach assumes that the popular uses of plants can offer strong clues to the biological activities of the plants. The results of the present study reveals the fact that the organic solvent extracts of ethanol, methanol was exhibited greater antimicrobial activities because the antimicrobial principles may be either polar or non polar nature.

Patil, (2009) reported the antifungal activity of ethanolic extract of the Leucasaspera leaves including anti-diarrhoeal, and antimicrobial, activities. Rana (1997) evaluated antifungal activity of essential oils isolated from the leaves of Bael using spore germination assay. The oil exhibited variable efficacy against different fungal isolates and $100 \%$ inhibition of spore germination of all the fungi tested was observed at 500ppm.They proposed that essential oil from bael leaves may interfere with the $\mathrm{Ca}^{++}-$dip colonic acid metabolism pathway and possibly inhibit the spore formation. 
Pitre and Srivastava, (1987), demonstrate the antifungal activity of ethanolic root extract against Aspergillus fumigatus

Sastry and Rao (1994) reported that, some of the bacterial strains (Proteus vulgaris, Micrococcus luteus and Bacillus megaterium) did not respond to solvents extracts, whereas the purified fractions showed broad spectrum activity against multiple strains. This might be due to masking of antibacterial activity by the presence of some inhibitory compounds or factors in the extract. The variation of antibacterial activity of our extracts might be due to distribution of antimicrobial substances, which varied from species to species as suggested by Lustigman and Brown (1991). Similar observations were made by Vlachos et al. (1997) who found that fractionation of crude extracts tested enhanced their activity against both Gram negative as well as the resistant gram positive pathogens.

Earlier antimicrobial studies using essential oils from Wattakaka volubilis leaves have demonstrated that terpenoid constituents in the oil are in vivo antifungal components by Balakumar et al., (2011). Tannins, eugenol, and cumin aldehyde contribute to the antibacterial activity of the fruit extract, particularly against Escherichia coli. In the present study, the phytochemical screening revealed the presence of alkaloid, anthraquinone, coumarin, flavonoid, phenol, saponin, steroid, tannin and terpenoid in the methanol and ethanol extracts of Wattakaka volubilis plant leaf, except steroids absence in methanol extract. In the DMSO extract alkaloids, anthroquinones and tannins are presence and others are absence, where as in Petroleum ether extract it contains alkaloids. Green plants represent a reservoir of effective chemicals. Therefore, the reason to believe that the activity of Wattakaka volubilis could be attributed to the presence of phytochemicals as done by the preliminary qualitative phytochemical analysis.

Hulin et al. (1998) reported plants are the major role in all traditional system of food and medicine. Plants contain rich source of variety of natural products, secondary metabolites such as tannins, terpenoides, alkaloids and flavonoides found in vitro to have antimicrobial properties. Biresh et al. (2011) reported that most of these properties are believed to be due to presence of bioactive alkaloids in Bael, antibacterial phytoconstituents such as tannins, saponins, flavonoids, alkaloids, anthocyanin, glycosides, terpenoids, triterpenoids, glycoside and phenols qualitatively isolated from Leucasaspera leaves which displayed potent antibacterial activity against Bacillus anthracis, Escherichia coli, and Klebsiellapneumoniae.

Wangensteen (2004) reported that leaves of Leucasaspera had more phenolic content than the seeds. All the extracts were studied for antibacterial activity against Escherichia coli, Staphylococcus aureus, Pseudomonas aeruginosa and Klebsiella pneumoniae. Of these, Leucasaspera methanolic extract showed zone of inhibition of $4.5 \mathrm{~mm}$ and $6 \mathrm{~mm}$ at concentration of $250 \mu \mathrm{g} / \mathrm{ml}$ and $500 \mu \mathrm{g} / \mathrm{ml}$ respectively against Klebsiella pneumonia while Coriander sativum diethyl ether extract showed zone of inhibition of $2.5 \mathrm{~mm}$ and $3.5 \mathrm{~mm}$ at a concentration of $250 \mu \mathrm{g} / \mathrm{ml}$ and $500 \mu \mathrm{g} / \mathrm{ml} \mathrm{respec-}$ tively against Staphylococcus aureus. Hence coriander has strong antibacterial activity. Research suggests that the volatile oils found in the leaves of the coriander plant may have antimicrobial properties against food borne pathogen Plant steroids are known to be important for their cardiotonic activities, possess insecticidal and antimicrobial properties. Plant derived natural products such as flavonoids, terpenoids and steroids etc have received considerable attention in recent years due to their diverse pharmacological properties including antioxidant and antitumor activity. Phenolic phytochemicals have antioxidative, antidiabetic, anticarcinogenic, antimicrobial, antiallergic, antimutagenic and anti-inflammatory (Arts and Hollmn, 2005).

Ragavendran et al. (2011) screened the functional groups of carboxylic acids, amines, amides, sulphur derivatives, polysaccharides, organic hydrocarbons, halogens that are responsible for various medicinal properties of Aervalanata analyzing the ethanolic extracts of Wattakaka volubilisby FTIR, revealed functional group components of amino acids, amides, amines, carboxylic acid, carbonyl compounds, organic hydrocarbons and halogens.
From the result obtained from the present investigation it is confirmed that the therapeutic potency of Wattakaka volubilis leaves, stem and flower were used as traditional medicinal values. In addition to these results it is a good basis for selection of the plant for all the investigation. The plant extract posses certain constitutions with antibacterial and antifungal properties caused by pathogens. The most active extract can be subjected to isolation of the therapeutic antimicrobials and carryout further pharmacological evolution. The results of our investigation confirmed the ration able process for the medicinal uses of important of the plant.

\section{Conclusion}

In the present investigation antibacterial activity of Wattakaka volubilis leaves tested against some clinically important bacteria like Bacillus pumilus, Enterobacteraerogens, E.coli and Pseudomonas aeruginosa. Four different solvents were uses viz., Ethanol, methanol, DMSO and petroleum ether. All the four genera showed resistance against DMSO and petroleum ether solvents, while in ethanol, zone of inhibition were observed in all the four. Preliminary phytochemical screening showed the presence of alkaloids, anthroquinoes, coumarin, flavonoid, phenols, saponins, steroid, tannins and terpenoid in ethanol extract. Except steroids all the above phytochemicals were observed in methanolic extract. In DMSO solvent extract only antroquinones and tannins were recorded. In petroleum ether extract only alkaloids were observed. The characterization of the plant extract and the functional groups was analyzed in Fourier Transform Infrared Spectroscopy (FTIR). The absorbance bands analysis were observed in the region of $4000-400 \mathrm{~cm}^{-1}$ are 23 compounds derived. The compounds represented the ranges from 3905.21 to 436.41 peaks were shown. Based on the above research work, it can be concluded that Wattakaka volubilis had good source for herbal drug and used to control pathogens.

\section{Acknowledgement}

Authors are highly acknowledged to Dr. P. Madhanraj, Director, Indian Biotract Research Institute, Thanjavur, Tamilnadu, India for providing facilities and valuable support to complete this work. Head department of Biotechnology, Sri Vinayaga College of Arts and Science, Ulundurpet, Tamil Nadu.

\section{References}

[1] Agarwal, V.S., (1986). Economic plants of India, KailashPrakashan, Calcutta: 116.

[2] Arts, I.C. andHollmn, P.C., (2005).Polyhenols are disease risk in epidemiological studies. American Journal of Clinical Nutrition $81: 317-325$.

[3] Balakumar, S., Rajan, S., Thirunalasundari, T., and Jeeva, S., (2011).Antifungal activity of Leucasaspera(L.)Correa(Rutaceae) leaf extract on dermatophytes. Asian. Pac. J.Trop Biomed; 309312.http://dx.doi.org/10.1016/S2221-1691(11)60049-X.

[4] Beyer, R.E., (1994). The role of ascorbate in antioxidant protection of biomembranes: interaction with vit-E and coenzyme. Q. J. Bioen. Biomemb; 24: 349-358.http://dx.doi.org/10.1007/BF00762775.

[5] Biju, P.G,,Gayatri, D.V., Lija, Y., and Abraham, A., (2007). Protection against Selenite Cataract

[6] Hulin, V., Mathot, A.G., Mafart, P. andDufosse L., (1998): Less proprieties anti-microbiennesdeshuilesessentialness composes drones. Sci.Aliments; 18: 563-582.

[7] Fatimah, Z.I., Zaiton, Z., Zamaludin, M., Gaptor, M.T., Nafeeza, M.L., Khairul, O., (1998).Effect on estrogen and palm vitamin F on malonaldehyde levels toward the development of arteriosclerosis in the New Zealand white rabbit. In: Packer L, Ong SH, editors. Biological Oxidants and antioxidants: Molecular Mechanism and Health Effects. Champaign IL: AOCS Press; 22.

[8] Molisha, B., Bikash, M.N., Partha, P., Ashoke, G. and Bannerjee, S. and Kanti, H.P., (2009). In vitro anti- leishmanial and anti-tumour activities of a pentacyclictriterpenoid compound isolated from the 
fruits of DregeavolubilisBenthAsclepiadaceae. Trop. J. Pharm. Res: 8(2): 127- 131.

[9] Raghavendra, M.P., Satish, S. and Raveesha, K.A., (2006). Phytochemical analysis and antibacterial activity of Oxalis corniculata: A known medicinal plant. My. Science; 1: 72-78.

[10] Raghavendra, M.P., Satish, S. and Raveesha, K.A., (2006). Phytochemical analysis and antibacterial activity of Oxalis corniculata: A known medicinal plant. My. Science; 1: 72-78.

[11] Thangavelu, T. Gnaphaliumpolycaulon, ShanmugapriyaKaminidevi, JinuUdayabhanu, SenthilMuruganThangave., (2015). Antimicrobial activity of methanolic extracts of indigenous traditional Indian folk Medicinal Plant. International Journal of Green Pharma$c y: 1-6$.

[12] Wangensteen, H.; Samuelsen, A.B. and Malterud, K.E., (2004) Antioxidant activity in extracts from coriander.Food Chem. 88, 293 297.http://dx.doi.org/10.1016/j.foodchem.2004.01.047.

[13] Yeh, G.Y., Eisenberg, D.M., Kaptchuk, T.J., Phillips, R.S., 2003 Systematic Review of Herbs and Dietary Supplements for Glycemic Control in Diabetes. Diabetes Care 26, 1277 1294.http://dx.doi.org/10.2337/diacare.26.4.1277.

[14] Guptha, A.K., Neeraj, T. and Sharma, M., (2005).Quality standards of Indian Medicinal Plants. Vol 3, ICMR,New Delhi; 9-19.

[15] Harbone, J.B., (1993). Phytochemistry,Acad.Press London, 21: 2785.

[16] Kirtukar, K.R and Basu, B.D., (2003). Indian medicinal plants, Bishen Singh Mahendrapal Singh, Dehradum; 3: 1635.

[17] Matthew, K.M., (1983). The Flora of Tamil Nadu Carnatic.InTheRapinatHerbarium.St Joseph's College, Tiruchirapalli, India

[18] Patil, R. H., Chaudhary, B., and Settipalli, S.,(2009). Antifungal and Antiaflatoxigenic activity of LeucasasperaLinn.PharmacognosyJournol.1 (4): 345-351.

[19] Pitre, S., and Srivastava S.K., (1987). Pharmacological, microbiological and phytochemical studies on the root of Leucasaspera.Fitoterapia 58: 194 -198.

[20] Rana, B. K., Singh, U. P. and Taneja, V., (1997). Anti-fungal activity and kinectics of inhibition by essential oil isolated from leaves of Leucasaspera.JEthanopharmacol; 57:29-34 http://dx.doi.org/10.1016/S0378-8741(97)00044-5.

[21] Ravi, K., Rajasekaran, S., Subramanian, S., 2005.Antihyperlipidemic effect of Eugenia jambolana seed kernel on streptozotocin induced diabetes in rats. Food and Chemical Toxicology 43, 1433 1439.http://dx.doi.org/10.1016/j.fct.2005.04.004

[22] Sastry, V.M.S., and Rao, G.R.K.,(1994). Antibacterial substance from marine algae: successive extraction using benzene, chloroform and methanol. Bot. Mar.37: 357-360. http://dx.doi.org/10.1515/botm.1994.37.4.357.

[23] Subbiah, V., (2005). Natural product based apoptosis inducers United States patent application 0084547

[24] Raghavendra, M.P., Satish, S. and Raveesha, K.A., (2006). Phytochemical analysis and antibacterial activity of Oxalis corniculata: A known medicinal plant. My. Science; 1: 72-78.

[25] Vlachos, V., Critchley, A. T., and Von Holy, A. (1997).Antimicrobial activity of extracts from selected Southern African marine macroalgae.SouthAfr J.Sci.93:328-332.

[26] Yoshimura, S., Narita, H., Hayashi, K. and Mitsuhashi H. (1983).Studies on the constituents of asclepiadaceae plants. LVI. Isolation of new antitumor-active glycosides from Dregeavolubilis(L.) BENTH.Chem Pharm Bull (Tokyo); 31:3971-83.

[27] Perez, C., Paul, M. and Bazerque, P., (1990).An antibiotic assay by the agar well diffusion method.ActaBiol Med Exp; 15: 113-115.

[28] Saifuddin, N., C.W. Wong and A.A. NurYasumira, 2009. Rapid biosynthesis of silver nanoparticles using culture supernatant of bacteria with microwave irradiation. E-J. Chem., 6: 6170.http://dx.doi.org/10.1155/2009/734264.

[29] Lustigman, B., and Brown, C., (1991). Antibiotic production by marine algae isolated from the New York/New Jersey Coast BulletinEnvironmental Contamination and Toxicology. 46:329 335.http://dx.doi.org/10.1007/BF01688928.

[30] Essawi, T. and Srour, M., (2000).Screening of some palestian medicinal plants for antibacterial activity.J. Ethanopharmacol; 70: 343-349.http://dx.doi.org/10.1016/S0378-8741(99)00187-7.

[31] Divya, T.S., (2009). Anti-inflammatory, analgesic and anti-lipid peroxidative properties of Wattakakavolubilis (L.f.) Stapf.Nat. Prod. Radi; 8(2):137-141.

[32] Vijayal, T., Devamma, N.M. and Nirmala, C., (2008).Antibacterial and antifungal activity of Marsdeniavolubilis in in vitroconditions.International seminar on medicinal plants.
[33] Sahu, N., Panda, N., Mandal, N.B., Banerjee, S., Koike, K. and Nikaido, T., (2002). Polyoxypregnane glycosides from the flowers of Dregeavolubilis.Phytochem; http://dx.doi.org/10.1016/S0031-9422(02)00260-1.

[34] Pandikumar P, Ayyanar M and Ignacimuthu S, 2007. Medicinal plants used by Malasar tribes of Coimbatore district, Tamil Nadu. Indian Journal of Traditional Knowledge, 6, 579-582.

[35] Silija VP, SamithaVarma K and Mohanan KV, 2008. Ethnomedicinal plant knowledge of the Mullukuruma tribe of Wayanad district, Kerala,Indian Journal of Traditional Knowledge,7, 604-612.

[36] Ayyanar M, SankaraSivaraman K and Ignacimuthu S, 2008. Traditional Herbal Medicines used for the treatment of Diabetes among two major tribal groups in South Tamil Nadu, India.Ethno Botanical Leaflet, 47:389-394.

[37] Fayyaz A., Asbi B.A., Ghazali H.M., Che Man Y.B. and Jinap S. 1994. "Purification and molecular properties of papaya pectinesterase", Food Chem., Vol.49, 373-378.http://dx.doi.org/10.1016/03088146(94)90007-8.

[38] Biresh, K, Jain Devananda, BannergeeAngush, 2011. New drug delivery system.IJRAP 2(5), 1513-1517. 